\title{
Peningkatan pH Saliva Perokok Aktif Menggunakan Permen Karet Xylitol
}

\section{The Increasing the pH of Active Smoker's Saliva using Xylitol Chewing Gum}

\author{
Wita Asmalinda ${ }^{1}$, Edy Sapada ${ }^{2}$, Yeni Agustin ${ }^{3}$ \\ ${ }^{1}$ Jurusan Kebidanan, Politeknik Kesehatan Kemenkes Palembang, Indonesia \\ ${ }^{2,3}$ STIK Siti Khadijah, Palembang, Indonesia
}

\section{ARTICLE INFO}

\section{Article history}

Received date

11 Oct 2021

Revised date

16 Oct 2021

24 Oct 2021

Accepted date

22 Nov 2021

Keywords:

$\mathrm{pH}$ of Saliva;

Smoker active;

Xylitol.

\section{Kata kunci:}

ph Saliva;

Perokok aktif;

Xylitol.

\author{
ABSTRACT/ ABSTRAK
}

Perokok aktif pada jangka waktu yang lama berdampak pada penurunan $\mathrm{pH}$ Saliva. Dampak yang paling nyata adalah pada reseptor kolinergik di otak yang mengaktivasi kerja saraf yang berakibat pada penurunan sekresi kelenjar saliva. Resiko penurunan fungsi saliva tersebut makin meningkat seiring dengan lamanya mengkonsumsi rokok dan jumlah batang perhari. Tujuan penelitian ini adalah untuk mengetahui pengaruh pemberian permen karet xylitol terhadap peningkatan $\mathrm{pH}$ saliva pada perokok aktif. Jenis Penelitan ini bersifat eksperimental uji klinis dengan kelompok pembanding (pretest and posttest with control group design). Penelitian ini dilaksanakan di Klinik Ibnu Sina Palembang selama 14 hari, pada tanggal 5-18 Desember 2020. Sampel dalam penelitian ini adalah perokok aktif yang memenuhi kriteria inklusi dan ekslusi. Jumlah sampel adalah 52 responden. Data karakteristik sampel dan hasil pengukuran dinilai homogenitasnya dengan mengunakan Uji Kolmogorov-Simov. Analisis deskripsi untuk mengetahui rerata dan standar deviasi. Terjadi peningkatan yang signifikan nilai rerata pH Saliva pada kelompok perlakuan. Disimpulkan bahwa permen karet xylitol berpengaruh terhadap peningkatan $\mathrm{pH}$ Saliva perokok aktif.

Corresponding Author:

Edy Sapada

STIK Siti Khadijah, Palembang, Indonesia

Email: edysapada@gmail.com

\section{PENDAHULUAN}

Kebiasaan merokok telah menjadi masalah nasional. Menjadi pencetus utama dan faktor resiko dari banyak penyakit kronis pada saluran pernapasan, penyakit jantung, stroke, kanker dan lain-lain (Priyambodo, et al., 2018).
Paparan asap dari perokok aktif mengandung lebih kurang 4000 bahan kimia berbahaya antara lain, tar, karbon monoksida, nikotin dan lain-lain (Saputri, 2018; Priyambodo, R Ardian, Nurindah. 2018; Sapada, 2020).

Menurut penelitian Priyambodo (2018) perokok aktif pada jangka waktu yang lama 
berdampak pada penurunan $\mathrm{pH}$ Saliva. Dampak yang paling nyata adalah pada reseptor kolinergik di otak yang mengaktivasi kerja saraf yang berakibat pada penurunan sekresi kelenjar saliva, mempengaruhi fungsi dan laju aliran saliva karena kerusakan pada jaringan dan sel (Saputri, 2018).

Ada beberapa faktor yang menjadi diduga menjadi penyebab turunnya $\mathrm{pH}$ saliva pada perokok aktif antara lain: efek dari paparan rokok saat menghisap rokok akan mengiritasi secara langsung mukosa mulut perokok. Kandungan bahan kimia yang terdapat pada rokok dan asap rokok akan mengaktivasi pelepasan sitokin dari sel makrofag dan neutrofil aktif seperti IL-1, prostaglandin 2, elastase 3, proteinase, katepasin G, yang pada prosenya akan merusak sel dan jaringan kelenjar saliva. Resiko penurunan fungsi saliva tersebut makin meningkat seiring dengan lamanya mengkonsumsi rokok dan jumlah batang perhari nya (Syukri, 2018).

Saliva merupakan sistem pertahanan dan proteksi pada mulut. Saliva mengandung; $99,5 \%$ $\mathrm{H} 2 \mathrm{O}, 0,5 \%$ elektrolit dan protein. Elektrolit seperti ion bikarbonat dan ion fosfat berperan dalam sistem buffer (Nugraheni, 2018; Larasati, 2016). Secara fisiologi, saliva diproduksi oleh glandula salivarius yang mempunyai peran penting untuk menjaga kesehatan rongga mulut (Wirawan, 2017). Fungsi terpenting saliva adalah kemampuannya dalam hal buffer, yang mengambil peran dalam mempertahankan Potensial of Hydrogen $(\mathrm{pH})$ saliva agar tetap netral, tidak asam dan tidak basa (Wirawan, E., 2017; Suratri, AL., 2017). Potensial of Hydrogen (pH) saliva ini berpengaruh terhadap pertumbuhan dan perkembangan bakteri mulut. $\mathrm{pH}$ saliva yang rendah $(4,5-5,5)$ mengakibatkan jumlah acid-sensitive bacteria menurun, sehingga terjadi gangguan pada sistem buffer (Nugraheni, 2018). Dalam prosesnya, hal ini diduga sebagai pencetus perkembangan bakteri lactobacillud fan Streptococcus (Suratri, 2017).

pH Saliva normal adalah pada kisaran 6,57,4 dalam keadaan yang demikian saliva mampu melaksanakan fungsinya untuk mengcover dan memperlancar kerja enzim pencernaan seperti ptyalin. Pada sistem imun humoral, saliva yang mengandung immunoglobulin (Ig) A, bekerja pada mukosa rongga mulut untuk mencegah perlengketan bakteri ataupun virus (Wirawan, 2017). Pada perokok aktif dengan paparan asap rokok yang rutin setiap hari, hal ini tentunya berdampak pada penurunan antibodi yang ada pada saliva, yang menyebabkan sistem pertahanan di rongga mulut akan menurun akibatnya daerah mulut akan rentan terinfeksi terutama oleh bakteri anaerob (Nugraheni, 2018; Priyambodo, 2018).

Menurut Istiqomah (2015) upaya mempertahankan keseimbangan asam basa di dalam rongga mulut adalah mengunakan cara mekanik dengan mengunyah, dan mengunakan cara kimiawi dengan berkumur-kumur. Penelitian Priyambodo (2018) dan penelitian Saputri, et al. (2018), menyatakan bahwa dengan intervensi pemberian permen xylitol pada perokok aktif berefek pada peningkatan $\mathrm{pH}$ (potensial of Hydrogen) saliva.

Penelitian yang dilakukan Milgrom (2009) dan Hidayati (2014) menunjukkan bahwa mengkonsumsi permen karet yang mengandung xylitol 4-10gram perhari dengan frekuensi minimal 3 kali perhari selama 14 hari terbukti mampu menurunkan bakteri Streptococcus pada saliva sampel. Permen xylitol apabila dikonsumsi setelah makan, sikat gigi, dan sebelum tidur akan memberikan efek positif, dapat memberikan sensasi segar dan dingin karena high endhotermic heat solution yang dimilikinya (Hidayati, 2014).

Penelitian terkait manfaat pemberian permen xylitol pada perokok aktif belum banyak dilakukan. Rumusan masalah pada penelitian ini adalah apakah ada perbedaan ph saliva pada kelompok yang diberikan permen karet yang mengandung xylitol dengan kelompok kontrol yang diberikan permen karet non xylitol. Tujuan penelitian ini adalah untuk mengetahui pengaruh pemberian permen karet xylitol terhadap peningkatan $\mathrm{pH}$ saliva pada perokok aktif. Diharapkan hasil penelitian ini dapat dijadikan dasar bagi penelitian lanjutan (evidence based) untuk mengembangkan dan pemanfaatan xylitol untuk kesehatan.

\section{METODE}

Jenis Penelitan ini bersifat eksperimental uji klinis dengan kelompok pembanding (pretest and post-test with control group design). Penelitian ini dilaksanakan di Klinik Ibnu Sina Palembang selama 14 hari, pada tanggal 5-18 Desember 2021 Sampel dalam penelitian ini adalah perokok aktif yang berkunjung di Klinik Ibnu Sina. Alasan memilih lokasi penelitian di Klinik Ibnu Sina adalah karena pada survey awal didapatkan dari 10 orang pengunjung klinik, 6 orang pengunjung adalah perokok aktif. Jumlah sampel sebanyak 52 orang, pengambilan sampel dilakukan secara purporsive sampling, klien yang ada pada waktu pengambilan sampel, yang memenuhi kriteria inklusi dan eksklusi diambil manjadi sampel. Untuk meminimalisasi faktor 
perancu (confounding factors) maka kepada setiap subjek penelitian dimintakan kesediaan untuk tidak mengkonsumsi permen karet yang mengandung xylitol dan tidak berkumur-kumur mengunakan larutan antiseptik 2 jam sebelum diambil sampel saliva pre dan sebelum diambil sampel saliva post. Untuk menentukan sampel masuk dalam kelompok perlakuan atau kelompok kontrol adalah dengan cara undian (lotre), sampel yang mendapatkan angka 1 dimasukkan dalam kelompok perlakuan dan mendapatkan angka 2 masuk ke dalam kelompok kontrol. Kepada semua sampel dijelaskan tujuan, prosedur, manfaat serta resiko sebagai sampel dalam penelitian ini. Setelah mendapatkan persetujuan sampel kemudian menanda tangani informed consent menjadi responden dalam penelitian ini. Variabel penelitian ini adalah variabel bebas (independen) permen xylitol dan variabel terikat (dependen) kadar $\mathrm{pH}$ Saliva. Pengambilan sampel saliva dan pemeriksaan $\mathrm{pH}$ Saliva dilakukan oleh petugas kesehatan dari Klinik Ibnu Sina Palembang. Alat digunakan dalam penelitian ini adalah Neerbecken, pot penampung saliva berwarna bening dengan ukuran 50mg, dental saliva $\mathrm{pH}$ indikator, baki, alat tulis, kamera, komputer dan jam tangan. Bahan yang digunakan adalah permen karet xylitol, handscond, face masker, tisu dan kapas. Prosedur pengambil sampel saliva adalah 2 jam sebelum dilakukan pengambilan sampel, responden diminta untuk tidak makan dan merokok. Secara bergantian sampel menerima pot untuk selanjutnya dilakukan pengambilan sampel. Dengan posisi duduk mengunakan metode spitting (saliva dikumpulkan ke dalam mulut sampai volume yang dibutuhkan lalu di keluarkan ke pot penampungan dalam posisi bibir tertutup) (Saputri, 2018). Sampel saliva yang terkumpul diberikan tanda mengunakan spidol untuk kelompok perlakuan dan kelompok kontrol. Pengambilan sampel saliva berlangsung selama 14 hari. Prosedur pengukuran $\mathrm{pH}$ saliva adalah dengan cara memasukkan elektroda $\mathrm{pH}$ meter. Sebelum dilakukan pengukuran $\mathrm{pH}$ saliva, penutup plastik elektroda dibuka, lalu dibilas dengan air deionisasi (air bebas ion) dan dikeringkan dengan tisu. Menyalakan $\mathrm{pH}$ meter digital dengan cara menekan tombol on/off. Elektroda dimasukkan ke dalam larutan buffer $\mathrm{pH}$ 7, putar elektroda agar larutan buffer homogen. Biarkan beberapa saat sampai nilai yang tertera pada display tidak berubah. Tekan tombol CAL pada layar. Tekan tombol hold/ent untuk menyempurnakan kalibrasi. Pada bagian layar akan muncul angka 7 yang menunjukkan $\mathrm{pH}$ meter tersebut telah dikalibrasi dengan buffer $\mathrm{pH}$ 7. Angkat elektroda dari larutan buffer 7, kemudian bilas dengan air deionisasi beberapa kali dan keringkan dengan kertas tisu, $\mathrm{pH}$ meter telah siap digunakan. Kemudian $\mathrm{pH}$ meter digital dihidupkan dengan menekan tombol on/off. Elektroda dimasukkan ke dalam sampel dan diputar agar larutan homogen. Dibiarkan sampai angka pada layar berganti dengan nilai saliva yang diukur pHnya. Lalu $\mathrm{pH}$ meter digital dimatikan dengan menekan tombol on/off (Saputri, et al., 2018). Mengamati dan mencatat kadar $\mathrm{pH}$ meter. Merapikan alat-alat dan membuang bahan habis pakai ke dalam bak sampah.

Komite Etik Penelitian kesehatan Politeknik Kesehatan Palembang memberikan Rekomendasi Lolos Kaji Etik pada Penelitian ini dengan No. 525 KEPK/ Adm 2//XII/2020.

\section{HASIL}

Data yang diperoleh dalam penelitian ini kemudian dianalisis secara statistik mengunakan aplikasi statistik, yang, yang meliputi uji homogenitas sampel mengunakan uji Kolmogorov-Simov, analisis deskriptif untuk mengetahui rerata dan standar deviasi. Data yang dihasilkan terdistribusi secara homogen.

Tabel 1. Karakteristik Responden

\begin{tabular}{llrrrrr}
\hline Variabel & \multicolumn{1}{c}{ n } & Min & Maks & Mean & Median & \multicolumn{1}{c}{ SD } \\
\hline - Umur (tahun) & 26 (perlakuan) & 19 & 62 & 38,88 & 41,00 & 14,381 \\
& 26 (kontrol) & 17 & 60 & 36,38 & 34,00 & 13,937 \\
- Konsumsi rokok & 26 (perlakuan) & 10 & 27 & 18,50 & 18,50 & 4,990 \\
(batang/hari) & 26 (kontrol & 10 & 28 & 16,96 & 16,50 & 4,521 \\
\hline
\end{tabular}

Dari tabel 1 menunjukkan bahwa dari 52 sampel didapatkan kisaran umur responden terendah adalah 17 tahun dan tertinggi adalah 62 tahun. Usia rerata responden kelompok perlakuan adalah 38,88 dan kelompok kontrol 36.88. Rerata konsumsi rokok kelompok perlakuan adalah 18,50 dan rerata konsumsi rokok kelompok kontrol adalah 16,96 
Tabel 2. Perbedaan Nilai Rerata pH Saliva Sebelum dan sesudah Pemberian Permen Karet Xylitol (Kelompok Perlakuan)

\begin{tabular}{lccrr}
\hline \multicolumn{1}{c}{ Variabel } & n & Rerata \pm SD & Min-Max & p-value \\
\hline pH Saliva pre & 26 & $6,3662 \pm 0,24057$ & $6,00-6,76$ & \multirow{2}{*}{0,0001} \\
pH Saliva post & 26 & $6,5873 \pm 0,24036$ & $6,12-7,00$ & \\
\hline
\end{tabular}

Dari tabel 2 menunjukkan bahwa nilai rerata $\mathrm{pH}$ Saliva responden kelompok perlaku sebelum diberikan permen karet Xylitol adalah $6,3662 \pm 0,24057$, sedangkan sesudah perlakuan sebesar 6,5873 $\pm 0,24036$ dengan selisih rerata adalah sebesar 0,2211. Hasil uji statistik mengunakan uji Paired t-test didapatkan nilai $p$ value $=0,000$ dengan nilai $\alpha=0,05$ ( $p$-value $<\alpha)$. Ho ditolak artinya ada perbedaan yang bermakna nilai rerata $\mathrm{pH}$ Saliva sebelum dan sesudah pada pemberian permen karet Xylitol.

Tabel 3. Perbedaan Nilai Rerata pH Saliva Sebelum dan Sesudah Permen Karet Non Xylitol (Kelompok Kontrol)

\begin{tabular}{lllrr}
\hline Variabel & n & Rerata \pm SD & Min-Max & p-value \\
\hline pH Saliva pre & 26 & $6,4338 \pm 0,23486$ & $6,00-6,82$ & 0,170 \\
pH Saliva post & 26 & $6,4196 \pm 0,22517$ & $6,05-6,80$ & 0,17 \\
\hline
\end{tabular}

Dari tabel 3 menunjukkan bahwa nilai rerata $\mathrm{pH}$ Saliva pre kelompok kontrol adalah $6,4338 \pm 0,23486$, sedangkan nilai rerata $\mathrm{pH}$ saliva post adalah sebesar $6,4196 \pm 0,22517$ dengan selisih rerata adalah sebesar 0,0142 . Hasil uji statistik mengunakan uji Paired t-test didapatkan nilai $p$-value $=0,170$ dengan nilai $\alpha=0,05$ ( $p$ value $>\alpha)$. Ho gagal ditolak artinya tidak ada perbedaan yang bermakna nilai rerata $\mathrm{pH}$ saliva pre dan post pada kelompok kontrol.

Tabel 4. Perbedaan Nilai Rerata pH Saliva Kelompok Perlakuan Permen Karet Xylitol dengan Kelompok Kontrol (Independent samples t-test)

\begin{tabular}{lrrrrr}
\hline \multicolumn{1}{c}{ Variabel } & n & \multicolumn{1}{c}{ Rerata \pm SD } & Min-Max & p-value \\
\hline pH Saliva Post Perlakuan & 26 & $6,5873 \pm 0,24036$ & $6,12-7,00$ & \multirow{2}{*}{0,012} \\
pH Saliva Post Kontrol & 26 & $6,196 \pm 0,22517$ & $6,05-6,80$ & \\
\hline
\end{tabular}

Dari tabel 5 menunjukkan bahwa nilai rerata $\mathrm{pH}$ Saliva post kelompok perlakuan permen karet Xylitol adalah 6,5873 $\pm 0,24036$, sedangkan nilai rerata $\mathrm{pH}$ Saliva post kelompok kontrol adalah sebesar 6,4196 $\pm 0,22517$, dengan selisih rerata adalah sebesar 0,1677 . Hasil uji statistik mengunakan uji Independens t-test didapatkan nilai $\mathrm{p}=0.012$ dengan nilai $\alpha=0,05$ ( $p$ value $<\alpha)$. Ho ditolak, hal ini menunjukkan ada perbedaan yang bermakna nilai rerata $\mathrm{pH}$ Saliva post pada kelompok perlakuan permen karet Xylitol dengan kelompok kontrol.

\section{PEMBAHASAN}

Dari hasil statistik terhadap pH Saliva pada kelompok perlakuan yang diberikan permen karet xylitol mengalami peningkatan yang bermakna. Ada perbedaan yang bermakna pada kelompok perlakuan dibandingkan dengan kelompok kontrol. Hasil penelitian ini sejalan dengan penelitian Priyambodo, et al. (2018) dan Geminisari (2011), bahwa terjadi peningkatan yang bermakna $\mathrm{pH}$ saliva perokok yang diberikan permen karet xylitol.

Perokok aktif adalah orang yang mengonsumsi rokok secara rutin setiap harinya (Saputri, et al., 2018). Kriteria perokok antara lain perokok ringan (1-10 rokok/hari), perokok sedang (11-19 rokok/hari), perokok berat (>20 rokok/hari) (Priyambodo, et al., 2018). Menurut penelitian Susana (2003), Asap rokok yang dilepaskan oleh perokok aktif ke lingkungan lebih banyak kadar nikotinnya dibandingkan yang terhisap oleh perokok itu sendiri. Hal tersebut diduga karena asap arus samping terus menerus dihasilkan selama rokok dinyalakan meskipun tidak di hisap. Pengaruh yang dirasakan oleh perokok aktif yang rutin mengkonsumsi rokok adalah pada suasana mulut yang kering, akibat turunnya aliran saliva dan $\mathrm{pH}$ saliva, keadaan yang dialami perokok aktif ini diduga sebagai faktor pencetus yang berpotensi memberikan tempat bagi perkembangan candida, yang sangat memungkinkan mengalami infeksi.

Menurut penelitian Rahma (2018) dan Jethlia (2016) merokok dalam jangka waktu pendek dapat berefek pada peningkatan laju 
aliran saliva. Hal ini diasumsikan bahwa kandungan nikotin dari produk tembakau diduga merupakan merupakan agonis kolinergik yang bekerja pada reseptor muskarinik yang secara fisiologi dapat mempengaruhi sistem saraf melalui asetilkolin, sehingga dapat merangsang sekresi saliva. Konsumsi nikotin pada dosis rendah, memberikan efek kolinergik (Gorrod, 2008) Struktur kimia nikotin sangat mirip dengan asetilkolin yang dapat mengaktivasi sistem saraf (Gorrod J, 2008). Hal sebaliknya dikemukan oleh beberapa penelitian yang mengungkapkan bahwa laju aliran saliva akan menurun signifikan pada perokok aktif jangka panjang. Reseptor asetilkolin akan terblok diakibatkan karena efek nikotin yang dikonsumsi secara rutin dan lama. Rangsangan kronik nikotin juga menyebabkan kelelahan (exhaustion) kelenjar saliva sehingga menurunkan sekresinya (Rahma, 2018; Jethlia, 2016). Rangsangan panas dari asap rokok di dalam mulut perokok diduga mempengaruhi aliran darah yang pada prosesnya turut mendukung penurunan sekresi saliva (Rahma, 2018).

Laju alir saliva akan menurun seiring pertambahan usia. Penurunan laju alir terkait usia ini terjadi $66 \%$ lebih besar pada saliva unstimulated daripada stimulated. Hal ini mungkin disebabkan karena laju alir saliva dari kelenjar submandibula dan sublingual lebih terpengaruh oleh usia dibandingkan kelenjar parotis, dimana kelenjar submandibula dan sublingual memberikan kontribusi $70 \%$ pada saliva tidak terstimulasi dan kurang dari $50 \%$ pada saliva terstimulasi. Penelitian pada sampel tikus yang dilakukan Choi (2013) mengungkapkan bahwa terjadi perubahan morfologi fungsional kelenjar saliva tikus. Sampel dengan usia tertua memiliki laju alir saliva paling rendah dibandingkan dua kelompok lain dengan usia lebih muda. Pada kelenjar saliva tikus tersebut ditemukan adanya atropi sel asinar, infiltrasi limfosit dan fibrosis periduktal yang lebih tinggi. Atropi sel-sel asinar terkait proses penuaan diduga akibat berkurangnya proliferasi seluler atau peningkatan apoptosis. Adanya filtrasi dari sel limfosit menunjukkan bahwa proses inflamasi juga berperan pada terjadinya perubahan degeneratif progresif akibat penuaan.

Fibrosis periduktal dapat menyebabkan kekakuan pada duktus yang akhirnya menimbulkan gangguan sekresi. Hal serupa diduga terjadi pada manusia usia lanjut, akibat disfungsi kelenjar saliva degenerasi (Choi, 2013). Penelitian Rahma (2018) menunjukkan bahwa adanya hubungan tidak searah antara laju aliran saliva dengan konsentrasi ion kalsium saliva. Konsentrasi kalsium saliva meningkat saat laju alir menurun baik pada perokok maupun bukan perokok. Menurut penelitian Khan (2010) peningkatan kalsium ini berhubungan dengan proses pembentukan dan sekresi saliva. Sel-sel sekretorik pada bagian ujung kelenjar saliva dan duktus interkalaris memproduksi saliva primer yang mengandung sebagian besar komponen organik dan seluruh air yang disekresikan oleh kelenjar saliva. Selanjutnya, saat saliva primer melewati duktus striata dan duktus ekskretorik, akan terjadi reabsorpsi dan sekresi aktif ion-ion sebelum akhirnya saliva keluar ke rongga mulut. Pada saat laju alir tinggi, tidak banyak waktu yang tersedia untuk terjadinya proses modifikasi tersebut sehingga konsentrasi ion-ion tersebut berbanding terbalik dengan laju alir. Dalam penelitiannya, Khan (2010) mengungkapkan bahwa salah satu ion yang memiliki hubungan tidak searah dengan laju alir adalah kalsium. Pada sampel dengan laju alir lebih tinggi tanpa adanya rangsangan eksogen, maka akan memiliki konsentrasi kalsium yang lebih rendah. Terjadinya reabsorpsi dan sekresi ion-ion saat saliva primer melewati duktus. Natrium akan direabsorpsi dan kalium akan disekresikan ke dalam saliva. Reabsorpsi natrium berbanding lurus dengan reabsorpsi air sehingga konsentrasinya akan relatif konstan meskipun laju alir bervariasi. Namun, berkurangnya jumlah air yang proporsional dengan berkurangnya laju alir, akan membuat kalsium menjadi lebih terkonsentrasi di dalam saliva. Hal tersebut yang menyebabkan konsentrasi kalsium saliva berbanding terbalik dengan laju alir saliva.

Peningkatan konsentrasi kalsium saliva pada perokok mungkin ada hubungannya dengan penurunan LAS dan $\mathrm{pH}$ perokok. Hasil penelitian menunjukkan terdapat korelasi antara penurunan LAS dan $\mathrm{pH}$ saliva dengan peningkatan konsentrasi ion kalsium saliva. Faktor lain yang mungkin menyebabkan peningkatan konsentrasi kalsium saliva pada perokok adalah penurunan kepadatan tulang. Perokok berat memiliki kepadatan tulang yang lebih rendah dan konsentrasi kalsium saliva yang lebih tinggi secara signifikan dibandingkan bukan perokok. Dari hasil penelitian tersebut disimpulkan bahwa penurunan kepadatan tulang secara langsung dapat meningkatkan konsentrasi kalsium di dalam saliva (Khan, 2010)

Saliva adalah cairan kompleks yang diproduksi oleh glandula salivarius, yang memiliki peran penting dalam menjaga rongga mulut (Wirawan, 2017). Kelenjar saliva yang utama adalah kelenjar parotis, submandibularis, dan sublingualis. Sekresi saliva normal adalah berkisar $800-1500 \mathrm{ml}$ (Guyton and Hall, 2014). 
Fungsi saliva lainnya adalah sebagai pelumas rongga mulut, komponen yang berperan adalah air dan musin yang dapat melindungi mukosa dari sisa makanan dan radikal bebas yang dapat menempel (Nugraheni, 2018; Larasati, 2016).

Salah satu fungsi saliva yaitu kemampuan buffer dimana kemampuan buffer ini dapat menahan turunnya $\mathrm{pH}$ atau meningkatnya asam mulut hal ini juga berkaitan dengan viskositas atau volume (Wirawan, 2017). Saliva disekresikan dengan kecepatan laju aliran saliva $20 \mathrm{ml} / \mathrm{jam}$ pada saat istirahat, hal-hal yang menyebabkan perubahan pada kecepatan laju aliran saliva salah satunya adalah paparan asap rokok. Rangsangan berupa rasa manis, asam, pedas dan pahit dapat mengaktivasi kecepatan sekresi saliva. Pemberian stimulan berupa rasa manis dan pedas dalam bentuk permen karet xylitol yang dikonsumsi secara rutin dengan dosis yang adekuat, dapat memfasilitasi viskositas saliva menjadi lebih encer. Peningkatan aliran saliva berbanding lurus dengan peningkatan kadar $p H$ saliva dan kapasitas buffer saliva (Istiqomah, N., 2015).

Saliva mengandung antibodi yaitu enzim peroksidase yang berperan mencegah bakteri dan virus masuk ke dalam tubuh. Selanjutnya protein yang terdapat dalam air liur, membantu aktivitas antimikroba dengan cara menghambat pertumbuhan bakteri. Protein yang terdapat pada air liur meliputi histatin, laktoferin, peroksidase, dan lisosim. Pada orang normal saliva memiliki peran sebagai pelindung basa antara lapisan mulut dan toksin. Merokok dapat memberikan dampak fisiologik terhadap saliva karena merokok dapat menghancurkan molekul dalam saliva yang berguna untuk melindungi rongga mulut. Merokok dapat memperpendek kehidupan seseorang sebesar enam menit setiap batang (Istiqomah, 2015). Asap rokok menyebar ke seluruh bagian rongga mulut dan reseptor rasa terkena paparan terus-menerus. Jika hal tersebut berlangsung dalam jangka waktu lama maka akan menyebabkan kurangnya sensitivitas dan perubahan reseptor dari indra perasa, dan lamakelamaan akan menyebabkan supresi refleks saliva. Radikal bebas yang terdapat pada rokok yaitu radikal hidroksil $(\mathrm{OH})$ dapat menyebabkan perubahan struktur dan fungsi molekul dalam saliva. Hal ini disebabkan oleh ion yang terdapat dalam saliva yang berperan dalam proses terbentuknya $\mathrm{OH}$. Hidroksil $(\mathrm{OH})$ dapat merusak tiga jenis senyawa yang penting untuk mempertahankan integritas sel. Salah satunya ialah asam amino penyusun protein yang ada dalam saliva. Asam amino yang paling rawan yaitu sistein. Sistein mengandung gugus sulfhidril (-SH) yang sangat peka terhadap serangan radikal hidroksil. Pembentukan ikatan disulfida (S-S) menimbulkan ikatan intra atau antar molekul sehingga protein (saliva) kehilangan fungsi biologiknya, dan bila protein tersebut berupa enzim maka enzim tersebut akan kehilangan aktifitas katalitiknya (Syukr, 2018).

Pusat saliva mengontrol derajat pengeluaran saliva melalui saraf otonom yang mensarafi kelenjar saliva. Stimulasi simpatis dan parasimpatis meningkatkan sekresi saliva tetapi jumlah, karakteristik, dan mekanisme yang berperan berbeda. Rangsangan parasimpatis berperan dominan dalam sekresi saliva, menyebabkan pengeluaran saliva encer dalam jumlah besar dan kaya enzim. Stimulasi simpatis menghasilkan volume saliva yang jauh lebih sedikit dengan konsistensi kental dan kaya mucus (Guyton and Hall, 2014).

Menurut Yulianto (2001) Xylitol adalah lima karbon polyalkohol, xylitol dimetabolisme di hati dan dikonversikan menjadi D-xylulose dan glukosa oleh polyol dehydrogenase. Secara kimia struktur xylitol terdiri dari lima atom karbon dan lima gugus hidroksil $\left(\mathrm{C}_{5} \mathrm{H}_{12} \mathrm{O}_{5}\right)$, tidak seperti gula lainya yang terdiri dari enam atom karbon, struktur seperti ini sangat sulit untuk dimetabolisme oleh bakteri sehingga xylitol secara komersial dilakukan melalui proses hidrogenasi xylosa $\left(\mathrm{C}_{5} \mathrm{H}_{10} \mathrm{O}_{5}\right)$ dengan bantuan katalisator nikel, pada suhu $8^{\circ}-14^{\circ}$ celcius, dan 50 tekanan atmosfer (Yulianto, 2001). Derajat kemanisan xylitol hampir sama dengan sukrosa, Bakteri oral diantaranya Streptococcus mutans bila kontan dengan xylitol akan terbentuk xylitol-5fosfat, yang mampu menghambat proses glikolisis.

Mengunyah permen karet menimbulkan refleks proses pengunyahan. Permen karet merupakan bolus yang dapat menyebabkan stimulus mekanis dan dapat merangsang peningkatan sekresi saliva, sedangkan sensasi pengecapan rasa pedas dari permen karet merupakan stimulus kimiawi yang juga dapat meningkatkan sekresi saliva (Rodian, 2011). Sebagai indera pengecap lidah memiliki reseptor pengecap rasa (taste buds). Rasa manis dari permen karet xylitol diasosiasikan sebagai rangsangan kimiawi yang diterima oleh taste buds, akan mengaktivasi sistem syaraf otonom yang selanjutnya akan merangsang sekresi kelenjar saliva. Gerakan mengunyah permen karet sebagai aktifitas mekanik, yang melibatkan fisiologi peredaran darah, saraf, otot-otot pengunyahan, sendi temporomandibularis dan gigi geligi turut mengaktivasi kerja saraf otonom untuk mensekresi saliva (Rezky, 2011; Guyton and Hall, 2014). Pada saat pengunyah permen 
karet xylitol, maka impuls pengecap di lidah akan diteruskan ke saraf lingualis, menuju nervus fasialis, terakhir ke traktus silitarius di batang otak (Guyton and Hall. 2014).

\section{DAFTAR PUSTAKA}

Choi JS, Park IS, Kim SK, Lim JY, Kim YM. (2013). Analysis of age-related changes in the functional morphologies of salivary glands in mice. Arch Oral Biol, 58,16351642.

Geminisari, Ni Nyoman. (2011). Permen Karet Xylitol Yang Dikunyah Selama 5 Menit Meningkatkan dan Mempertahankan $\mathrm{pH}$ Perokok Selama 3 Jam. [Tesis]. Bali: Program Pasca Sarjana, Universitas Udayana.

Gorrod J, Tsai M. Nicotine. (2008). The tobacco alkaloids. In: Waring RH, Steventon GB, Mitchell SC eds. Molecules of death. 2nd ed. London: Imperial College Press, 2008: 241.

Guyton and Hall. (2014). Text Book Physiology Medicine. (Edisi $11^{\text {th }}$ ). Jakarta: EGC.

Hidayati, N Annisa, Kaidah, S, Sukmana, B Indah. (2014). Efek Pengunyahan Permen Karet yang Mengandung Xylitol Terhadap Peningkatan pH Saliva. Dentino Jurnal Kedokteran Gigi, 2(1).

Istiqomah, N., dan Santoso, B. (2015). Pengaruh Berkumur Larutan Daun Binahong terhadap pH Saliva pada Ibu Hamil Desa Babadan Kabupaten Semarang. Jurnal Kebidanan, 3(9), 31-36.

Jethlia A, Kelusker V, Lunkad H. (2016). Biochemical alterations in saliva of tobacco users: A case control study. Int $J$ Contemp Dent 7:1-5.

Khan GJ, Javed M, Ishaq M. (2010). Effect of smoking on salivary flow rate. Gomal Journal of Medical Sciences, 8(2), 221.

Larasati, A. (2016). Perbedaan Derajat Keasaman (pH) Saliva pada perokok Kretek dan Non kretek. [Skripsi]. Jakarta: Fakultas Kedokteran dan Ilmu Kesehatan, Universitas Islam Negeri Syarif Hidayatullah.

\section{SIMPULAN}

Berdasarkan hasil analisis, bahwa terjadi peningkatan yang signifikan nilai rerata $\mathrm{pH}$ Saliva kelompok perlakuan yang diberikan permen karet xylitol, maka dapat disimpulkan bahwa pemberian permen karet xylitol berpengaruh terhadap peningkatan $\mathrm{pH}$ saliva pada perokok aktif. Disarankan untuk dilakukan penelitian lebih lanjut pada tingkat molekuler terhadap parameter $I L-1$, prostaglandin 2 .

Milgrom P, Ly KA, Rothen M. (2009). Xylitol and Its Vehicles for Public Health Needs. Adv Dent Res, 21, 44-47.

Nugraheni, F. (2018). Gambaran Derajat Keasaman $(\mathrm{pH})$ Saliva pada perokok $E$ Cigarette, Perokok Cigarette dan Non Perokok. [Skripsi]. Jakarta: Fakultas Kedokteran, Universitas Islam Negeri Syarif Hidayatullah.

Priyambodo, R Ardian, Nurindah. (2018). Pengaruh Menguyah Permen Karet Terhadap pH Perokok. Media Kesehatan Gigi, 17(1). http://www.journal.poltekkesmks.ac.id/ojs2/index.php/mediagigi/articl e/view/165 (diakses pada 28 April 2019).

Rahma. (2018). Efek Merokok terhadap Laju Alir, pH dan Konsentrasi Ion KAlsium Saliva pada Perokok di Asrama Yon Arhanudse 11/BS Batera, R. [Skripsi]. Medan: Fakultas Kedokteran Gigi, Universitas Sumatera Utara.

Rezky, LK., dan Handajani. (2011). Efek Mengunyah Permen Karet Gula dan Xylitol terhadap Status Saliva. Majalah Kedokteran Gigi, 18(1), 21-24.

Rodian, M., Satari, MH., dan Rolleta, E. (2011). Effect of Chewing Gum Containing Sucrose, Xylitol and Probiotic to Saliva Characteristic. Dentika Dental Journal, 16(1), 44-48.

Sapada, IE and Asmalinda, W. (2020). The Vital Lung Capacity of Employees with Risk Factors for Potential Exposure to Ammonia Gas. Jurnal Ilmu dan Teknologi Kesehatan, 8(1), 1-13.

Syukri, DM., Suling, PL., dan Minjelungan. (2018). Nilai pH Saliva pada Buruh Perokok di Pelabuhan Bitung. Jurnal eGiGi (eG), 6(2), 96-100.

Saputri, D., Ningsih, D.S dan Dewi R.r. (2018). The Description of Salivary $\mathrm{pH}$ from Active Smokers and Passive Smokers on 
The Society at District Mesjid Raya Aceh Besar. Journal Cakradonya Dental,10(2), 107-112.

http://www.jurnal.unsyiah.ac.id/CDJ.

Suratri, AL., Jovina TA., dan N. Tjahja, I. (2017). The Effects (pH) of Saliva by Dental Caries Occurrence in Pre-School Children Age. Buletin Penelitian Kesehatan, 45(4), 241-248.

Susana, D., Hartono, B., Fauzan, H. (2003). Penetuan Kadar Nikotin Dalam Asap
Rokok. Jurnal Ekologi Kesehatan, 2(3), 272-274.

Wirawan, E., dan Puspita, S. (2017). The Effect of Saliva $\mathrm{pH}$ and Buffer Capacity on DMF-T and def-t in The Mixsed Teeth Children (6-12 Years Old). Insisiva Dental Journal, 6(1), 25-30.

Yulianto, W.A. 2001. Pengaruh pH, Kadar Xilosa dan Kadar Glukosa Terhadap Produksi Xylitol Oleh Candida shehatae WAY 08. Jurnal Teknol dan Industri Pangan. 12(2), 156-163. 